\title{
Biochar Effects on Carbon Stocks in the Coffee Agroforestry Systems of the Himalayas
}

\author{
Ngamindra Dahal ${ }^{1}$, Roshan Man Bajracharya ${ }^{1} \&$ Lal Mani Wagle ${ }^{2}$ \\ ${ }^{1}$ School of Science, Kathmandu University, Nepal \\ ${ }^{2}$ Southasia Institute of Advanced Studies, Nepal \\ Correspondence: Ngamindra Dahal, School of Science, Kathmandu University, Nepal. E-mail: \\ ngamindra@gmail.com
}

Received: July 22, 2018 Accepted: August 17, 2018 Online Published: September 19, 2018

doi:10.5539/sar.v7n4p103 URL: https://doi.org/10.5539/sar.v7n4p103

\begin{abstract}
Coffee agroforestry is an emerging agricultural practice in the mid hills of Nepal. Smallholder farmers of low-income strata have progressively adopted coffee as a perennial crop over seasonal crops. A multi-year study was conducted to test effects of locally produced biochar derived from coffee wastes, e.g., pulp and husks, on carbon stocks of: i) coffee trees, and, ii) soil organic carbon (SOC) in selected coffee growing pockets. We conducted on-farm experimental trials in three different physiographical locations of the Nepal mid-hills, namely, Chandanpur (Site I at 1475masl), Panchkhal (Site II at 1075masl), and Talamarang (Site III at 821masl) where smallholders grow coffee together with other cereal crops and vegetables. We applied biochar to the soil at a rate of $5 \mathrm{Mgha}^{-1}$, then, monitored the SOC and biomass growth of the coffee trees in the three treatment plots at sites I, II and III over two years beginning in 2013. The average stocks of aboveground carbon in coffee trees increased from 6.2 $\pm 4.3 \mathrm{Mgha}^{-1}$ to $9.1 \pm 5.2 \mathrm{Mgha}^{-1}$ over the trial period of two years in biochar treated plots. The same in control plots increased from 5.6 $\pm 2.8 \mathrm{Mgha}^{-1}$ to $6.7 \pm 4.7 \mathrm{Mgha}^{-1}$. In the biochar plots, the average increments of ABG carbon was $0.73 \mathrm{Mgh}^{-1}$ while in the control it was $0.29 \mathrm{Mgh}^{-1}$. Analysis of soil organic carbon of the plots indicated overall incremental change in carbon stocks in the coffee farms. During the base year, the average SOC stocks in the top $0-15 \mathrm{~cm}$ layer of the soil at sites I, II, and III were estimated $74.88 \pm 15.93 ; 63.96 \pm 16.71$ and 33.05 $\pm 4.42 \mathrm{Mgha}^{-1}$ respectively. Although both the biochar treated and control plot registered incremental change in SOC stocks, the volumes were remarkably higher in the former than the latter. Compared to the baseline data, the changes in SOC stocks in the three biochar treated plots were 19.8, 49.8 and 45.3 $\mathrm{Mgha}^{-1}$, respectively, whereas in the control plots these were 8.3,29.3 and $11.3 \mathrm{Mgha}^{-1}$, respectively. The higher incremental rates of C-stocks in all the biochar treated plots in comparison to the corresponding control plots of the coffee agroforestry implies that application of biochar can enhance accumulation of carbon in the form of aboveground biomass and soil organic carbon.
\end{abstract}

Keywords: mountain farmers, coffee waste, biochar, aboveground carbon stocks, soil organic carbon, hill agricultural systems and biochar treated soils

\section{Introduction}

Globally, agroforests (AFs) contribute significantly to sequester and store carbon (C) in the form of aboveground and belowground biomass and soil organic carbon (Nair, 2011). Agroforestry systems have higher potential to sequester C than pastures or field crops (Kirby and Potvin, 2007). Over 630 million hectares of unproductive croplands and grasslands are available for conversion into agroforestry systems to potentially sequester 1.43 and $2.15 \mathrm{Tg}\left(10^{12} \mathrm{~g}\right)$ of $\mathrm{CO}_{2}$ annually by 2010 and 2040, respectively (IPCC, 2000). Such a potential indicates an instrumental role that AFs can play to moderate climate change depending on strategies of adaptation e.g. retaining soil nutrients and moisture, and mitigation e.g. enriching soil organic matter or carbon (OM or SOC). Limited studies on the $\mathrm{C}$ stock dynamics in various agroforestry systems remain a constraint to harness these potentials (Jose and Bardhan, 2012). It has been reported that the average SOC in South and Southeast Asia is $8.7 \mathrm{~kg} / \mathrm{m}^{2}$ which is considerably lower than the global average of $11.3 \mathrm{~kg} / \mathrm{m}$ (Dahal et al., 2010).

Coffee agroforestry (CAF), a sub component of agroforestry systems (AFS), is identified as potential source of carbon pooling under land use systems (Noponen et al., 2013). With more than 1000 million (M) ha of CAF area coverage globally, this system is a principal component among the various AFS of (Nair et al., 2009a), therefore, 
carries an enormous potential for sequestrating $\mathrm{C}$ in the forms of aboveground and belowground biomass with expanding trends (Albrecht and Kandji, 2003; Soto-Pinto et al., 2010; Verchot et al., 2007). Studies undertaken by Segura et al., (2006) in Nicaragua and Negesh et al., (2013) in Ethiopia are among few appropriate models available for estimating carbon stocks in CAF system, and, the former is considered more appropriate for the CAF practices in the Himalayas where majority of farms including the experimental plots have adopted coffee Arabica variety.

The middle hills of the Himalaya that passes through Nepal ranges between the altitudes of 800 and $2400 \mathrm{~m}$ forms a complex mosaic of the rugged terrain, cross-crossed by rivers and valleys, and receive $80 \%$ of annual rainfall during monsoon between June to September. During the four months of rainy summer, farmlands, forests and barren lands are covered with rapid growth of vegetation when the annual stock of above-ground biomass (AGB) reaches at its peak before it starts decline in the subsequent months. However, the Mid Hills have been densely settled and intensively cultivated for several centuries by replacing natural forests with arable crops, which means the AGB was greatly reduced, often to <10\% of the original (Sharma et al., 2008). Deforestation also depleted the quantity of organic matter in the soils, to about one half of the contents under forest in topsoils and to about two-thirds in subsoils. The loss of forest AGB and litter plus the decline in soil organic matter mean that $\mathrm{C}$ storage in the Middle Hills have been greatly reduced (Dahal and Bajracharya, 2011). The decreases in organic matter content and the substitution with nitrogenous fertilisers degrade soil physical fertility, and lead to coarse hard clods, lower soil moisture retention, and poorer workability (Pilbeam et al., 2005). The farmers of the Middle Hills have adapted to these conditions and developed management systems that integrate crops, livestock, forestry, and grassland. They are able to sustain substantial rural populations at subsistence levels on very small farms (Carson, 1992; Tamang, 1991). Common elements in the heterogeneous traditional systems include crop rotation, fallows, grazing of crop residues, zero grazing, irrigation where water is accessible and manageable, and the application of farmyard manure (FYM) (Schreier and Shah, 1999; Suwal et al 1991).

Majority of mountain farmers of Nepal and the Himalayas eke out their livelihoods through subsistence agriculture practices in the non-irrigated uplands locally known as bari (Dahal, 2012). Mountain regions have seen production of major cereal crops virtually stagnant for over the past 15-20 years (Kaini et al., 2004), some of the main reasons for the low yield are believed to be the lack of replenishment of SOC together with inadequate and inappropriate use of fertilizers (Bajracharya et al., 2004, Shrestha et al., 1995 and UNEP, 2012). Over half of the 75 districts of Nepal are categorized under the food-insecure region (FAO, 2009), and nearly all of them fall in the hilly or mountain region. This is an irony for the region where majority of population live on agricultural business. As a consequence, farmers tend to look opportunities for transforming their traditional upland crops such as maize, potato and green vegetables with multi-year crop such as coffee and fruits which have high value in the market. In recent decades, sizable smallholders in the hilly terraces of the Himalaya grow coffee as a perennial crop. According to an estimate, about 20,000 families are engaged in the production of coffee in Nepal (Ghimire, 2009), thus, generating more than 7,700 full-time employment equivalent (ITC 2007). In order to reap benefits of high market value of coffee, they have converted their conventional crop growing uplands into coffee agroforests. The change in the hilly landscape is spectacular after perennial coffee bushes have replaced seasonal crops in the range between $800 \mathrm{~m}$ and $1600 \mathrm{~m}$ altitudes. Potential coffee production area in Nepal has been estimated to be around 1.9M ha (MoAD, 2014).

The climate and topography of the lower Himalayas, specifically soils, altitude range, and hilly landscape are conducive to coffee farming where vast potential exists for its expansion (Table 1). Despite the growing demand of Nepali coffee in the local and international markets, farmers have found reasons to grow perennial crops such as coffee relative to seasonal crops. The hardship of practicing agriculture manually in hilly terrains, particularly maintaining and replenishing optimum level of manures to the soil, has been a driving factor to farmers to adopt agro-forestry system. Traditionally, Nepali hill farmers practiced subsistence agriculture and relied mostly on farmyard manure (FYM) and some compost to replenish plant nutrients in soils. Although farmers find the FYM and compost beneficial to their lands, rising labor costs and intangible benefits (slow and indirect returns) remain the major constraints for their sustainable uses. In turn, industrial fertilizers are widely applied over the FYM although the latter is still on practice in limited scales (Bajracharya and Sherchan, 2009). With the advent of modern agricultural practices from low intensity (subsistence oriented) to more intensive cropping (commercial), farmers depend more on chemical fertilizers rather than FYM, which they find labor intensive. Nevertheless, a significant number of hill farmers continue to use FYM particularly those who have adopted an improvised practice called 'sustainable soil management or SSM' as this helped them make FYM more effective and sustainable (Dahal and Bajracharya, 2012). Marschner (2006) elaborates that plant productivity is directly influenced by nutrient availability, which is a product of nutrient transformations in the soil environment. More 
recently, agencies working in the field of hill agriculture have introduced biochar as a measure to tackle the issue of productivity and SOC losses (Dahal and Bajracharya, 2013).

Several studies have highlighted efforts of the mountain farmers in maintaining soil quality against degradation of soil fertility, surface erosion, and landslides (Biswokarma et al., 2014, Regmi et. al., 2005, Bajracharya and Atreya, 2007, SSMP, 2009, and, Dahal and Bajracharya, 2011). Among other actions, they use farm yard manure (FYM) in bari every year that contributes to maintain or enhance soil organic matter, thus, sequestrating carbon in the form of SOC. The FYM is prepared with waste biomass from agriculture fields and forest litter mixed with dung from livestock. These are few of their good practices that they are doing from generations, on which there are limited studies regarding impacts of such practices on soil carbon pool.

Biochar, a pyrolysis product of biomass wastes, is used as organic additive for soil amendment to improve soil health, thereby, increase crop yields and productivity through reduced soil acidity, enhancing water retention, and minimizing the needs of some chemical and fertilizer inputs (Glaser et al 2002; Lehmann and Rondon, 2006). Applications of biochar in agricultural fields have dual impacts- effect on soil quality and plant production (Lehmann, 2007). In addition to its direct contribution of available nutrients to the soil, biochar has a variety of physical and chemical properties that influence soil nutrients transformations (Deluca et al., 2009). This study further indicates that biochar additions to soil have the potential to change the microbial biomass, community composition and activity of soil microbes, all of which can influence nutrient mineralization from decomposing plant residues as well as several specific nutrient transformations. According to Pietikäinen and Fritze, (1993) the porous structure of biochar offers habitat to proliferate soil microbes. Likewise, a study by Major et al., (2010) has discussed positive effects of biochar on plant growth and associated C inputs, and those by DeLuca et al (2006) and Ni et al., (2010) highlighted sorption effects of biochar on microbial signaling compounds or inhibitory plant phenolic compounds as well as its effect on soil physical and chemical properties.

Biochar as a stable substance of soil organic matter (SOM) accounts for its dual roles in carbon stock enhancement in the soil (Anders et al., 2012). First, its particles remain locked in the soil with limited or no decomposition, and second, its catalyzing effect, which accelerates mineral uptake capacity of the plants that contributes to prevent mineral leaching. This study aimed to evaluate biochar effects on C-stocks in coffee agroforestry plantations to give a new dimension of knowledge on biochar. Taking cases of expanding coffee agroforestry practices in the mid-hills of Nepal, this paper analyzes biochar effects on the total carbon stocks of agroforestry systems in the Himalayas.

However, inadequate understanding about the specific mechanisms through which biochar influences soil microbial community properties remains as a bottleneck (Lehmann et al., 2011). Nevertheless, roles of organic inputs including FYM, compost and biochar for soil amendment and maintaining soil health have been widely recognized although precautionary note such as of Mukherjee and Lal, (2014) continue to emerge against exaggeration of about its merits over demerits.

\section{Materials and Methods}

Research sites: The three experimental sites of this study represent a diverse geo-climatic feature of the Himalayas where mountain or hill farmers of Nepal have a tradition of farming in a distinct manner. On-farm field trials were undertaken between 2013 and 2015 in three locations of Nepal mid hills at altitudes between $821 \mathrm{~m}$ to $1475 \mathrm{~m}$ that reflect an agro-ecological diversity of the Himalayas. The trials were conducted in the private farms where the smallholders produce Arabica coffee variety together with other cereal crops and vegetables. The three sites exhibit a diverse characteristic of the middle Himalayas dominated by densely populated river valleys, rivers, hillocks and agriculture based livelihoods along the hilly terrains where contrasting micro-climate variation exists as the altitudes, aspects, and slopes vary. Site I, Chandanpur, is located at $1475 \mathrm{~m}$ facing south of the Mahabharat range, has terraced field with average slopes of 20 degree and the soil with loam texture. Site II, Panchkhal, lies at 1075m in the central mid hills facing northeast with 25 degrees on average slope, and the soil with silt loam texture. Likewise, Site III, namely, Talamarang, is situated at an altitude of $821 \mathrm{~m}$ near the bank of the snow-fed Melamchi River from the Himalayas to the northern part of the mid hills. The average slope of the coffee farm is 15 degrees facing to the east with soil texture of sandy silt loam. The different locations of the experimental sites fairly capture diversity of micro-climatic variations as they are apart from each other between 20 to $80 \mathrm{~km}$ and exhibit contrasting climatic variations although all these sites receive over $80 \%$ of annual rainfall volumes during the four months of monsoon (June to September). The coffee growers often rely on a manual of organic coffee producers (MOAD, 2014) developed by supporting agencies including the Department of Agriculture.

Among the coffee growing farmers, a couple of households were selected in each site for the trials based on their 
willingness to participate voluntarily in biochar making and application on their respective plots. These were farmers who had been growing coffee for 5 years or more, and, willing to participate voluntarily. Accordingly, farmers offered their full cooperation to identify plots, tag sampled trees, and collect soil samples as well as measure biomass from the designated plots. Monitoring an effect of biochar trial in a farmer's field environment of coffee agroforestry was undertaken carefully to ensure that the trial plots get same level of treatments than the rest of the fields. During the trials, the farmers, who own the lands of the experimental plots, continued their regular activities including pruning and removal of diseased trees.

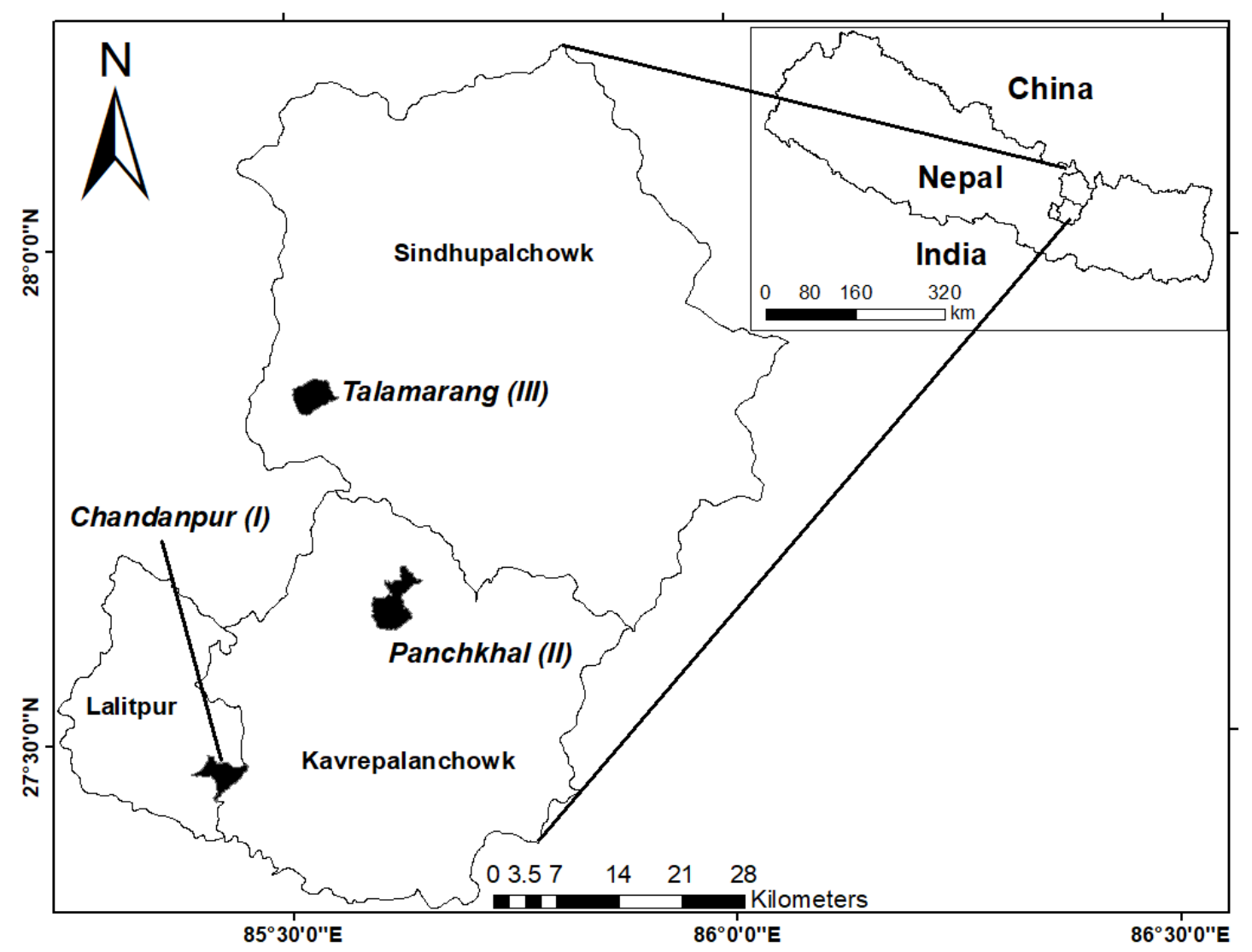

Figure 1. Map showing the locations of the research sites in Nepal

The individual smallholders who switched parts of their traditional maize and millet growing lands to coffee agroforestry are driven by the interest of maximizing benefit over their conventional farming practices. The evolving coffee agroforestry systems in the region are among the least studied in terms of carbon stocking. With three trial plots that represent a diverse climatic context, this study reported the results and analyses of the trials undertaken from farmers' fields. 
Table 1. Geographical characteristics of the experimental plots established in each of the three coffee growing belts of Lalitpur, Kavrepalanchok and Sindhupalchok districts of Nepal

\begin{tabular}{|c|c|c|c|c|c|c|c|c|c|}
\hline $\begin{array}{l}\text { Locations of } \\
\text { experimental plots }\end{array}$ & $\begin{array}{l}\text { Latitude, } \\
\text { Longitude }\end{array}$ & $\begin{array}{l}\text { Elevation / } \\
\text { Type* }\end{array}$ & $\begin{array}{l}\text { Size of trial } \\
\text { plots }\end{array}$ & $\begin{array}{l}\text { Number of } \\
\text { coffee trees } \\
\text { per plots }\end{array}$ & $\begin{array}{l}\text { Number of trees } \\
\text { per hectare }\end{array}$ & $\begin{array}{l}\text { Current coffee } \\
\text { area in the district* }\end{array}$ & $\begin{array}{l}\text { Potential coffee } \\
\text { area in the } \\
\text { district** }\end{array}$ & $\begin{array}{l}\text { Dominant } \\
\text { soil texture }\end{array}$ & $\begin{array}{l}\text { Soil organic } \\
\text { matter } \\
\text { (SOM) }\end{array}$ \\
\hline $\begin{array}{l}\text { I. Chandanpur, } \\
\text { Lalitpur }\end{array}$ & $\begin{array}{l}27^{\circ} 28^{\prime} 36.16^{\prime \prime} \mathrm{N}, \\
85^{\circ} 24^{\prime} 50.02^{\prime \prime} \mathrm{E}\end{array}$ & $\begin{array}{l}1475 \mathrm{~m} \\
\text { Upland }\end{array}$ & $\begin{array}{l}100 \mathrm{~m}^{2} \text { out of } \\
0.3561 \text { ha } \\
\text { planted area }\end{array}$ & 655 & 1840 & $90 \mathrm{ha}$ & 8548 ha & Silt loam & $10 \%$ \\
\hline $\begin{array}{l}\text { II. Panchkhal, } \\
\text { Kavrepalanchok }\end{array}$ & $\begin{array}{l}27^{\circ} 37^{\prime} 48.08^{\prime \prime} \mathrm{N}, \\
85^{\circ} 36^{\prime} 21.32^{\prime \prime} \mathrm{E}\end{array}$ & $\begin{array}{l}1075 \mathrm{~m} \\
\text { Upland }\end{array}$ & $\begin{array}{l}100 \mathrm{~m}^{2} \text { out of } \\
0.4578 \text { ha } \\
\text { planted area }\end{array}$ & 960 & 2097 & 116 ha & 3679 ha & Silt loam & $3.5 \%$ \\
\hline $\begin{array}{l}\text { III. Talamarang, } \\
\text { Sindhupalchok }\end{array}$ & $\begin{array}{l}27^{\circ} 51^{\prime} 15.90^{\prime \prime} \mathrm{N} \\
85^{\circ} 32^{\prime} 43.15^{\prime \prime} \mathrm{E}\end{array}$ & $\begin{array}{l}821 \mathrm{~m} \\
\text { Upland }\end{array}$ & $\begin{array}{l}100 \mathrm{~m}^{2} \text { out of } \\
0.2543 \text { ha } \\
\text { planted area. }\end{array}$ & 535 & 2104 & 95 ha & 19427 ha & Sandy loam & $3 \%$ \\
\hline
\end{tabular}

*The upland type of land category usually represents a rainfed agricultural land in the hill agricultural system, which is locally known as bari in the local term and perceived as a low grade compared to the khet due to latter's access to irrigation. ** Source: MOAD, 2014.

Design of experimental plots: Taking account of the local practices of plantation density, which is approximately 4000 trees per hectare, experimental plots was designed of the size covered by 40 coffee trees $\left(100 \mathrm{~m}^{2}\right)$ in each of the farms in the three locations, namely, Chandanpur, Panchkhal and Talamarang of Nepal (table 1). The sizes of the three farms where the plots established were of $0.2543 \mathrm{ha}, 0.3561$ ha and 0.4578 ha with number of trees 535, 655 and 960 respectively. All these farms were older than 8 years and, each of the trees were matured enough for annual harvesting of fruits (cherries). Using a stratified random sampling approach, 120 coffee trees were identified and tagged, 40 each from the three sites for monitoring of biomass growth. The farmers were advised to carry on their business as usual way without differentiating their activities including pruning, trimming, harvesting and intercropping of the vegetable crops of their choices in the treatment areas from rest of the farm areas. Accordingly, they followed their usual practices. The height and basal diameter at $15 \mathrm{~cm}$ of the tagged 120 coffee trees were measured. Effect of farmers' preferences on height of coffee tree was observable as they carry out cutting and pruning as well as intercropping of seasonal vegetables. The follow up monitoring of the sites was conducted. Of the 120 tagged trees, biochar was applied to the 60 ( 20 from each of the 3 experimental sites), and rest 60 (20 each from the respective sites) were left with no-biochar treatment for control.

Soil sampling: Soil samples were collected from the experimental plots prior to the treatment with biochar. The samples were taken from top layer soil $(0-15 \mathrm{~cm})$ with five replications from the three experimental plots. A corer of $100 \mathrm{~cm}^{3}$ was used for measuring bulk density (Blake and Hargte, 1986). The baseline sampling was followed immediately by applications of biochar as follows: 1 ) out of the 120 coffee trees (40 each from the three sites), half or 60 of them ( 20 from each site) were identified as 'biochar treated', and rest 60 as control (as discussed earlier). 2) Applied biochar to the soil of the 60 tagged trees within a radius of $57 \mathrm{~cm}$ at a rate of 5 ton/ha (5 $\mathrm{Mgha}^{1}$ ). The samples were tested in the university lab for SOC composition, and, 3 . The process of soil sampling and testing was repeated identically after 2 years for a comparison of the results.

Biochar production and application as a soil amendment agent: Biochar was produced using coffee waste materials as a feedstock in a specially designed stove for dual purposes of preparing biochar while cooking animal feed at household levels (Dahal and Bajracharya, 2013). Coffee wastes were considered an appropriate feedstock types as these are the least recycled refuses compared to other locally generated biomass wastes. Wastes generated through processing of coffee beans from pulping centers are abundantly available during harvesting months of December and February. A variety of coffee processing wastes such as pulps, husks, and discarded cherry beans; and those produced from cutting and pruning of coffee trees are mixed up together to prepare the feedstock as these are not preferred for feeding cattle or composting (Dahal et al, 2013). Low temperatures 350 and 550 degrees Celsius was maintained in order to prevent burning the pyrolysed feedstock into ashes. For the purpose of testing biochar effects on the coffee plants, 500 grams of mixed biochar was applied to each of the 60 coffee trees (50\% of those selected for trial, leaving the rest $50 \%$ as control) in the three sites. The biochar input area was within the radius of $57 \mathrm{~cm}\left(1 \mathrm{~m}^{2}\right.$ area $)$ of each tree, which is equivalent to 5 $\mathrm{Mgha}^{1}$. The soils and bichar were tested prior to the application of biochar. Basic properties of baseline samples of soil and biochar are presented in the table 2 . 
Table 2. General properties of soils at pre-treatment stage and sample of applied biochar

\begin{tabular}{llllc}
\hline Parameters & Chandanpur & Panchkhal & Talamarang & Sample of applied biochar \\
\hline pH & 6.026 & 5.8 & 5.23 & 8.54 \\
Soil Organic Matter (SOM) \% & 10.37 & 6.564 & 5.758 & 19.47 \\
Bulk Density (gm/cm3) & 0.83 & 2.012 & 1.956 & - \\
Total Nitrogen (ppm) & 1388.8 & 3281.6 & 2396.8 & 14840 \\
Available Phosphorus (ppm) & 137.6 & 520.04 & 323.36 & 5273 \\
Available Potassium (ppm) & 267.96 & 244.78 & 202.84 & 1386 \\
CEC (m. e./100gm) & 59.44 & 49.64 & 39.36 & 90 \\
\hline
\end{tabular}

Estimation of coffee tree biomass: In each of the three trial sites, 20 coffee trees were identified and applied biochar while another set of 20 coffee trees were tagged as control for the purpose of biomass monitoring based on tree height and stem diameter at $15 \mathrm{~cm}$ above the ground $\left(\mathrm{d}_{15}\right)$ to estimate biomass stock of each tree. In the absence of specific biomass equation for the coffee plant grown in Nepal, the best fitted model developed by Segura et al (2006) was applied, which was derived based on the extensive field trials from 37 coffee farms in Nicaragua; and, is expressed as:

$$
\log _{10}\left(\mathrm{~B}_{\mathrm{T}}\right)=\mathrm{a}+\mathrm{b} * \log _{10}\left(\mathrm{~d}_{15}\right)+\mathrm{c} * \log _{10}(\mathrm{~h})
$$

Where $\mathrm{B}_{\mathrm{T}}$ is total aboveground biomass of an individual coffee tree in kilogram; $\mathrm{a}, \mathrm{b}$ and $\mathrm{c}$ are the model's fitted parameters with values $1.113,1.578$ and 0.581 , respectively; $d_{15}$ is stem diameter at $15 \mathrm{~cm}$ height $(\mathrm{cm})$, and plant height (h) in $\mathrm{m}$. According to this model, the total above ground biomass of each coffee plant ranged from 0.005 to $2.8 \mathrm{~kg}$. Carbon values were derived from biomass values using a conversion factor "carbon fraction" (CF) of 0.47 (Adale, et al., 2006). Based on monitoring of $d_{15}$ and $\mathrm{h}$, the aboveground biomass of the tagged plants was measured two times; first between April to June at the time when biochar was applied, and, second in the same months after two years.

Estimation of SOC stocks: The soil organic carbon (SOC) in the top soil layer $(0-15 \mathrm{~cm})$ was estimated using Pearson et al., (2007) approach, and, expressed as: SOC $\left(\mathrm{Mgha}^{-1}\right)=\mathrm{SC} / 1000 * \mathrm{BD} * \mathrm{SD} * 10000 \mathrm{Mg} \mathrm{ha}^{-1}$; where SOC is total soil carbon pool in $\mathrm{Mg} \mathrm{ha}^{-1}, \mathrm{SC}$ is concentration of soil C in $\mathrm{gkg}^{-1}$ soil, BD is bulk density in $\mathrm{gcm}^{-3}$, and SD is soil depth in m. We compared the changes in SOC stocks between the treatment and control plots separately in each of the three locations, namely, Chandanpur, Panchkhal and Talamarang (table 1).

Statistical Analysis: To illustrate specific treatment effects, an ANOVA test was carried out on changes in AGB carbon and SOC stocks among the plots at the three sites using minitab 17 version. Similar analyses were conducted on changes in SOC stocks. The results are presented graphically as SOC stocks in $\mathrm{Mgha}^{-1}$ for carbon accounting, and for assessing the net impact of treatments on ecosystem carbon storage and, thus, their potential for climate change mitigation.

\section{Results}

Aboveground Carbon Stock: Comparative results of pre-treatment (base year) stage with those of post-treatment stage are presented in the table 3 for both biochar treated and control plots. Results of two years of monitoring of aboveground biomass at the three sites generally indicated incremental stocks of carbon. Of the two plots, with and without biochar amendment, growth rates were higher in the former, implying the positive effect of biochar on the coffee plants. Both the biochar applied and non-biochar plots showed modest increments.

The average stocks of aboveground carbon in coffee trees increased from $6.2 \pm 4.3 \mathrm{Mgha}^{-1}$ to $9.1 \pm 5.2 \mathrm{Mgha}^{-1}$ over the trial period of two years in biochar treated plots. The same in control plots increased from 5.6 $\pm 2.8 \mathrm{Mgha}^{-1}$ to $6.7 \pm 4.7 \mathrm{Mgha}^{-1}$. Specific to experimental plots, the stocks in site I increased by $4.65 \mathrm{Mgha}^{-1}$ followed by 3.04 $\mathrm{Mgha}^{-1}$, and $1.02 \mathrm{Mgha}^{-1}$ in sites III and II respectively. Farmers' maintenance of plant height of coffee tree is common. In site I and III, coffee growers maintained relatively taller size as they perceive better harvest in taller trees compare to shorter one. The farmers at site II, however, maintained relatively shorter heights for the ease of harvesting coffee cherries, which is reflected in the carbon volumes as well as Site II recorded lower amounts compared to the rest two sites. In the biochar plots, the average increments of ABG carbon was $0.73 \mathrm{Mgh}^{-1}$ while in the control it was $0.29 \mathrm{Mgh}^{-1}$. These different rates of change may be explained as a biochar effect on biomass growth. We didn't account the fruits as this involved a tedious task of maintaining tree specific records of intermittent harvest over a period of several weeks or a month. 
Table 3. Results of above-ground carbon stocks of coffee agroforestry systems over two years after application of locally produced biochar at the rate of $5 \mathrm{Mgha}^{-1}$

\begin{tabular}{|c|c|c|c|c|c|}
\hline $\begin{array}{l}\text { Experimental } \\
\text { Sites }\end{array}$ & Treatments & $\begin{array}{l}\text { Number of } \\
\text { Samples (n) }\end{array}$ & $\begin{array}{l}\text { Base Year (Mean } \quad \pm \\
\text { Standard deviation in } \\
\text { Mgha }^{-1} \text { ) }\end{array}$ & $\begin{array}{l}\text { Number of } \\
\text { samples (n) }\end{array}$ & $\begin{array}{l}\text { Post treatment stage (after two } \\
\text { years) (Mean } \pm \text { Standard } \\
\text { deviation in } \mathbf{M g h a}^{-1} \text { ) }\end{array}$ \\
\hline \multirow[t]{2}{*}{ I. Chandanpur } & Control & 20 & $6.95 \pm 5.12$ & $16^{*}$ & $10.19 \pm 7.92$ \\
\hline & $\begin{array}{l}\text { Biochar } \\
\text { applied }\end{array}$ & 20 & $7.57 \pm 3.01$ & 20 & $12.22 \pm 5.18$ \\
\hline \multirow[t]{2}{*}{ II. Panchkhal } & Control & 20 & $3.27 \pm 1.48$ & 20 & $3.50 \pm 1.12$ \\
\hline & $\begin{array}{l}\text { Biochar } \\
\text { applied }\end{array}$ & 20 & $3.56 \pm 2.8$ & 20 & $4.58 \pm 2.76$ \\
\hline \multirow[t]{2}{*}{ III. Talamarang } & Control & 20 & $6.58 \pm 4.23$ & 20 & $6.59 \pm 5.07$ \\
\hline & $\begin{array}{l}\text { Biochar } \\
\text { applied }\end{array}$ & 20 & $7.43 \pm 6.99$ & $19^{*}$ & $10.47 \pm 7.83$ \\
\hline \multirow[t]{2}{*}{ Average } & Control & & $5.6 \pm 2.8$ & & $6.7 \pm 4.7$ \\
\hline & Biochar & & $6.2 \pm 4.3$ & & $9.1 \pm 5.2$ \\
\hline
\end{tabular}

*The number indicates that farmers removed the diseased coffee trees, which occurred on those in two control plots but no such issues occurred in the plots treated with biochar.

The incremental growth of C-stocks in the biochar applied plots was higher than those for the non-biochar plots in all the three sites. Analysis of variance (ANOVA) suggests that the incremental rates of the aboveground carbon stocks are statistically significant, both by location and by treatment (table 4).

Table 4. ANOVA test result using Minitab version 17 indicates significant effects of treatment and location on the aboveground carbon stocks of coffee trees in biochar treated plots

\begin{tabular}{llllll}
\hline Source & DF & Adj SS & Adj MS & F-Value & p-Value \\
\hline Location & 2 & 50.60 & 25.300 & 12.61 & $0.000^{* *}$ \\
Treatment & 1 & 16.76 & 16.761 & 8.35 & $0.005^{* *}$ \\
Replication & 19 & 32.92 & 1.733 & 0.86 & 0.627 \\
Error & 97 & 194.62 & 2.006 & & \\
Total & 119 & 294.90 & & & \\
\hline
\end{tabular}

The C-tocks in the initial stage (pre-treatment) and final stage (post treatment at the end of year 2) are presented in a simple graph with trend lines (figure 2). Crossing of the two trendlines each other may be interpreted as an effect of biochar treatment on the C-stocks build up in the trees.

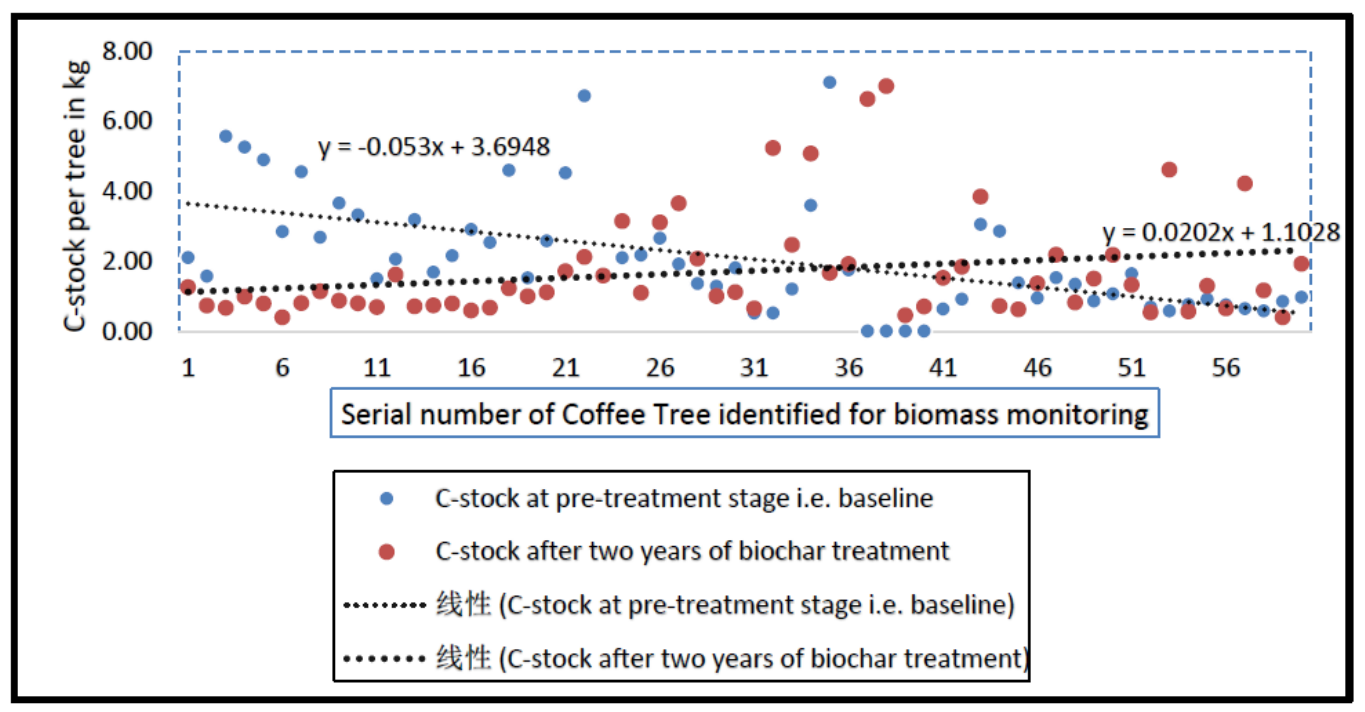

Figure 2. Changes in C-stocks in coffee trees at pre-treatment and post-treatment stages. Crossing of the trendlines between the pre and post treatment stages over the two years after biochar application indicate an effect of biochar 
Changes in stocks of soil organic carbon (SOC): In the base year, 2013, the average stock in the three sites: I, II, and III, was $74.88 \pm 15.93 ; 63.96 \pm 16.71$ and $33.05 \pm 4.42 \mathrm{Mgha}^{-1}$, respectively. The disparity in SOC stocks of coffee farms among the three locations as indicated by figure 2 reflects the diverse characteristics of soils as well as farming practices including inputs provided in the forms of compost and FYM over a decade or more as determinant factors (Biswokarma et al, 2014). Incremental changes in SOC stocks were observed in all the biochar treatment plots (Figure 3) compared to baseline estimates. The changes in SOC stocks in the three biochar treated plots of Chandanpur, Panchkhal and Talamarang were higher with 19.8, 49.8 and $45.3 \mathrm{Mgha}^{-1}$, respectively, compared to $8.3,29.3$ and $11.3 \mathrm{Mgha}^{-1}$ in the corresponding control plots. A wide range of incremental changes of SOC in biochar treated plots and control during the study period evidently offers a positive indication for interpretation regarding a cause-effect relation between biochar and SOC.

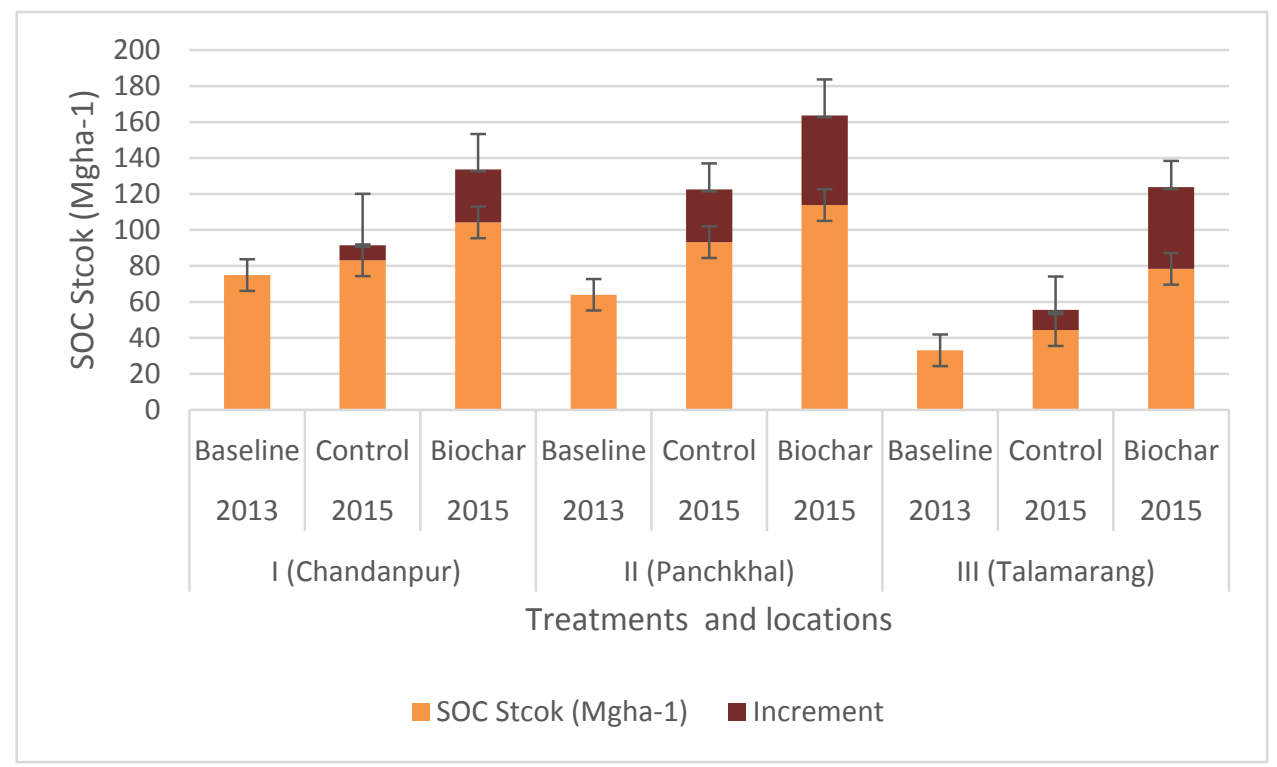

Figure 3. Changes in SOC stocks $\left(\mathrm{Mgha}^{-1}\right)$ with biochar treatment in the top soil layer

In spite of different level of baseline SOC stocks in the three experimental sites, which is as expected due to decades of agricultural practices and natural composition of soils, the higher rates of incremental changes of SOC in all the biochar treated plots compared to the control plots is evident. This implies a positive indication of biochar effects on SOC stocks although the results are subject to validity with larger scale trials.

\section{Discussion}

Among the plots, higher amount of stocks were recorded in those where pruning is less frequent, and, taller size of trees were maintained (for example in Talamarang) than those where pruning/trimming was practiced regularly (for example in Panchkhal). These findings may serve as a reference for incentivizing the agroforestry farmers with carbon co-benefits in the future. Major aspects of findings of this study are discussed in the subsequent sections below.

Carbon stock in coffee agroforestry: We estimated the aboveground biomass carbon of the coffee plants applying Segura et al., (2006) model, which was derived from Nicaraguan coffee agroforestry context. Basal diameter $\left(\mathrm{d}_{15}\right)$ and tree height are the key parameters of this model. The results are comparable to the findings of similar studies in Guatemala by Schmitt-Harsh et al (2012) who recorded above-ground C-stocks of $12.9 \mathrm{Mgha}^{-1}$ on an average. The figure is in close agreement to our estimates of Site I (12.22 $\left.\mathrm{Mgha}^{-1}\right)$ and Site III (10.47 Mgha $^{-1}$ ) but higher than those of Site II (4.58 Mgha ${ }^{-1}$ ). According to Nair et al., (2009b) SOC stocks are higher in agroforestry system compared with treeless seasonal crop systems. As our study did not include carbon stored in shade trees and understory vegetable crops, these results are not comparable with the total carbon stocks of agroforestry systems including shade trees. Two of the three farms under this study have no shade trees (sites I and III), hence, may be categorized as 'sun coffee' and the remaining farm (Panchkhal, the site II) can be categorized under limited shade trees. In order to enhance applicability of the model to estimate aboveground carbon stocks of coffee trees in the Himalayan context, further field trials are imperative for three reasons. First, the results can be analyzed against two baselines- changes in carbon stocks along a timeline and, - in situ change the emerging practices of coffee agroforestry; second, it is not clear whether the model has taken the fruits into 
account or not, and third, some of the coffee trees were diseased and removed from plots during the follow up monitoring leading to lower estimation.

Biochar effects on growth of coffee plant: The incremental effects of the aboveground carbon stocks of coffee trees in the two of the three plots of this study may be attributed to biochar action together with some minerals and micronutrients available in it to stimulate the tree growth. The results also indicate higher rates of incremental change in biochar treated plots compared to the control or no-biochar plots although not all the increments were statistically significant. These findings corroborate with the results of a long term research by Noponen et al., (2013) in the coffee agroforestry of Nicaragua and Costa Rica where inputs of organic mineral are credited for the increased stocks of carbon on the top soils. A recent study by Gautam et al., (2017) about an effect of biochar on crop systems in the hilly agricultural systems of the Himalaya demonstrated that effectiveness of biochar was even higher on SOC increment when applied together with FYM with a result of 2\% increase with biochar alone and 6\% increase with biochar plus FYM.

Effectiveness of biochar on soil SOM: The average rates of increase of SOC in biochar applied plots in comparison of control indicate an effect of biochar treatments at various levels. The incremental carbon stocks are remarkably higher in soil than those of trees. In the farmer's field, the growth of carbon stocks, however, may not be attributed to biochar only but other factors including biomass inputs in the form of organic compost and farm yard manure as well. The overall results suggest that biochar effectively plays a stimulating role to improve the organic matter status where it is deficient. It leads to reduce susceptibility of soil erosion, thus, lower retention of fertilizers and less production of crops and further depletion of SOM in the hilly region. Likewise, Dahal and Bajracharya, (2012) reported the SOC level in parts of mid hills Nepal, namely, Baglung, Dhading, Kavre and Okhaldhunga, within the range of 23 to $47 \mathrm{Mgha}^{-1}$ in the top layer $(0-15 \mathrm{~cm})$, which were remarkably higher than this study. The difference could be the result of differences in the nature of agricultural practices where sustainable soil management practices were introduced. Reports of incremental change in SOC stocks after changes in agricultural management is based on extrapolation from rates of C-sequestration by growing plants using weak evidence about the processes by which this might influence the $\mathrm{C}$-stocks, which can be positive or negative (Sanderman and Jeffrey, 2010). Pointing to the vicious cycle of SOC depletion, Lal, (2009) depicted two major causes. The first is the long-term use of extractive farming practices and, the second is the conversion of natural ecosystems such as forest and grass lands, into croplands where SOC stocks suffer losses due to a number of factors like low biomass input, tillage practices, crop harvesting, excessive inputs of chemical fertilizers, and soil erosion. This is important because protection of surface soils in the hilly agricultural landscape remains a critical challenge particularly when intense rainstorms are common during the pre-monsoon and monsoon months (March to September). High degree of erosivity and erodibility of the hilly slopes make the top soils and nutrients with organic matter vulnerable to erosion losses.

Benefits of biochar to the local coffee growers: Smallholders coffee growers who actively cooperated in this study were particularly interested in three benefits of biochar effects; first, the quantity and quality of fruits (volume and size of cherries), second, the soil properties (acidity, compactness, moisture retention), and, third, carbon sequestration benefits. This study reports the positive effects of biochar for enhancing carbon sequestration, which is on the interest of the local farmers as they may fetch incentive for a contribution to reduce emission. CAF systems as a potential source of above- and below-ground C-sequestration may offer dual opportunities of climate adaptive and economic benefits.

\section{Conclusions}

The practice of conversion of conventional upland agricultural lands of the Himalaya into various types of agroforests including coffee is gaining popularity in recent years. This makes the mid-hills coffee agroforestry a new source of carbon stock in the agricultural fields. Effects of biochar on carbon stocks of coffee agroforests were studied at on-farm sites of three location of Nepal mid hills with an intent to understand carbon dynamics in the aboveground biomass and top soils in the Himalayan context. A remarkable finding of this study is the increase in carbon stocks of 3 agroforestry farms in 3 districts of eastern Nepal after application of biochar at a nominal rate of 5 tons per hectare. Specifically, the growth coffee trees leading to higher biomass carbon, and SOC were noted to be higher in biochar applied plots compared to non-applied plots, although not all the changes were statistically significant. The study also indicated that biochar can be more effective to enhance carbon stocks in soils than those of tree biomass. As the study was undertaken in a limited environment of coffee agroforests with no cover of shade trees and farmers' field, a longer term and comprehensive study covering both in a controlled environment and sizable number of on-farm sites is a prerequisite for a conclusive finding.

It was noted that a major challenge in estimating carbon stock accurately in on-farm agroforestry systems is due 
to the heterogeneous interventions such as understory or intercropping practices and fertilizers. Such interventions were not monitored closely and may have affected the results. Anthropogenic factors that affect biomass stock of a coffee tree exist due to the preferential management practices of cutting and pruning of the coffee trees usually in the period from 1 to 3 years.

\section{Acknowledgements}

The authors are thankful to the Helvetas Intercooperation for providing technical support to undertake field study, and Aquatic Ecology Centre (AEC) of Kathmandu University for conducting lab analysis of soil samples. The authors remain thankful to the coffee growing farmers of Chandanpur, Panchkhal and Talamarang for their support and hearty cooperation for this study.

\section{References}

Anders, A., Hanley, K., Whitman, T., Joseph, S., \& Lehmann, J. (2012). Characterization of biochars to evaluate recalcitrance and agronomic performance. Bioresource Technology, 114(2012), 644-653. http://dx.doi.org/10.1016/j.biortech.2012.03.022 .

Albrecht, A., \& Kandji, S. T. (2003). Carbon sequestration in tropical agroforestry systems: review. Agric Ecosyst Environ, 99, 15-27. https://doi.org/10.1016/S0167-8809(03)00138-5

Bajracharya, R. M., \& Atreya, K. (2007). Carbon Sequestration in the Upland Farming Systems in the Nepal Midhills. Proceedings of Conference on Environment. Tribhuvan University, Nepal. June 22-24.

Bajracharya, R. M., \& Sherchan, D. L. (2009). Fertility status and dynamics of soils in the Nepal Himalaya: A review and analysis. In: Soil Fertility. (Eds. D. P. Lucero and J. E. Boggs). Nova Science Publishers, Inc.

Bishwakarma, B. K., Dahal, N. R., Allen, R., Rajbhandari, N. P., Dhital, B. K., Gurung, D. B., Bajracharya, R. M., \& Baillie, I. C. (2014). Effects of improved management and quality of farmyard manure on soil organic carbon contents in smallholder farming systems of the Middle Hills of Nepal, Climate and Development.

Blake, G. R., \& Hartge, K. H. (1986). Bulk Density, in A. Klute, ed., Methods of Soil Analysis, Part I. Physical and Mineralogical Methods: Agronomy Monograph, 9(2nd ed.), 363-375.

Carson, B. (1992). The land, the farmer and the future: A soil fertility management structure for Nepal. International Centre for Integrated Mountain Development. Occasional Paper 21.

Dahal, N., \& Bajracharya, R. M. (2013). Use of biochar for enhancing soil quality in mountain agricultural lands of Nepal. Proceedings of International conference on forest, people and climate: Changing paradigm (Eds. Balla, M. K., Rayamajhi, S. and Singh, A). Institute of Forestry, Pokhara, Nepal.

Dahal, N., \& Bajracharya, R. M. (2011). Prospects of soil organic carbon sequestration; Implications for Nepal's mountain agriculture. Journal of Forest and Livelihood, 9, 1-14.

Dahal, N., \& Bajracharya, R. M. (2012). Effects of sustainable soil management practices on distribution of soil organic carbon in upland soils of Mid-hills of Nepal. Nepal Journal of Science and Technology, 13, 133-141.

Dahal, N., \& Bajracharya, R. M. (2011). Prospects of soil organic sequestration: Implications for Nepal's Mountain Agriculture. Journal of Forest and Livelihood, 9(1). https://doi.org/10.3126/jfl.v9i1.8593

Dahal, N., Bajracharya, R. M., \& Merz, J. (2014). Soil Properties and Carbon Stock Quantification in Coffee Agro-forestry of Mid-Hills Nepal. In: Proceedings of International Conference on Forests, Soil and Water. Kathmandu University, Dhulikhel, Nepal.

Dahal, N. R. (2012). Prospects of enhancing soil organic carbon in sloping farm terraces of Mid Hills Nepal through sustainable soil management practices. Thesis submitted for M.Phil. Degree to the Department of Environment Science and Engineering, Kathmandu University.

Deluca, T., Mackenzie, M. D., \& Gundale, M. J. (2009). Biochar Effects on Soil Nutrient Transformations. Biochar for Environmental Management: Science and Technology. 251-270.

DeLuca, T. H., MacKenzie, M. D., Gundale, M. J., \& Holben, W. E. (2006). Wildfire-produced charcoal directly influences nitrogen cycling in forest ecosystems. Soil Science Society America Journal, 70, 448-453. https://doi.org/10.2136/sssaj2005.0096

Gautam, D. K, Bajracharya, R. M., \& Sitaula, B. K. (2017). Effects of Biochar and farm yard manure on soil properties and crop growth in an agroforestry system in the Himalaya. Sustainable Agriculture Research, 
6(4). https://doi.org/10.5539/sar.v6n4p74

Ghimire, D. (2009). Institutional System and Current Status of Coffee in Nepal (in Nepali) Tea - Coffee - 2066. NTCDB, Kathmandu.

Glaser, B., Lehmann, J., \& Zech, W. (2002). Amerliorating physical and chemical properties of highly weathered soils in the tropics with charcoal - a review. Biology and Fertility of Soils, 35, 219-230. https://doi.org/10.1007/s00374-002-0466-4

IPCC (2000). Land-use, land-use change, and forestry. A special report of the IPCC. In: Watson RT, Noble IR, Bolin B, Ravindranath NH, Verardo DJ, Dokken DJ (eds). Cambridge University Press, p 375

ITC (2007). Export Potential Assessment in Nepal. International Trade Centre, Geneva

Kirby, K. R., \& Potvin, C. (2007) Variation in carbon storage among tree species: implications for the management of a small scale carbon sink project. For Ecol Manag, 246, 208-221. https://doi.org/10.1016/j.foreco.2007.03.072

Lal, R. (2009). The Potential for Soil Carbon Sequestration. In Agriculture and climate change: An Agenda for negotiation in Copenhagen for Food, Agriculture and the Environment. IFPRI Policy Brief, 5, 16

Lehmann, J., Rillig, M. C., Thies, J., Masiello, C. A., Hockaday, W. C., \& Crowley, D. (2011). Biochar effects of soil biota - A review. Soil Biology and Biochemistry, 43, 1812-1836. https://doi.org/10.1016/j.soilbio.2011.04.022

Lehmann, J. (2007). Bio-energy in the black. Frontiers in Ecology and the Environment, 5, 381-387. https://doi.org/10.1890/1540-9295(2007)5[381:BITB]2.0.CO;2

Lehmann, J., \& Rondon, M. (2006). Biochar soil management on highly weathered soils in the humid tropics. In: Biological approaches to sustainable soil systems (Uphoff, N. editor). Boca Raton (FL): CRC Press. https://doi.org/10.1201/9781420017113.ch36

Major, J., Lehmann, J., Rondon, M., \& Goodale, C. (2010). Fate of soil-applied black carbon: downward migration, leaching and soil respiration. Global Change Biology, 16, 1366-1379. https://doi.org/10.1111/j.1365-2486.2009.02044.x

Marschner, H. (2006). Mineral Nutrition of Higher Plants. Second ed., Amsterdam: Academic Press, 890 pp.

MoAD (2014). Coffee Database in Nepal. Ministry of Agricultural Development, Government of Nepal. Retrieved from http://teacoffee.gov.np/images/gallery/coffee_database_in_nepal_2014_.pdf

Mukharjee, A., \& Lal, R. (2014). Biochar dilemma. Soil Research, 52, 217-230. https://doi.org/10.1071/SR13359

Nair, P. K. R., Kumar, B. M., \& Nair, V. D. (2009a). Agroforestry as a strategy for carbon sequestration. J. Plant Nutrition. Soil Science, 172, 10-23. https://doi.org/10.1002/jpln.200800030

Nair, P. K. R., Nair, V. D., Kumar, B. M., \& Haile, S. G. (2009b). Soil carbon sequestration in tropical agroforestry systems: a feasibility appraisal. Environ. Sci. Pollution, 12, 1099-1111. https://doi.org/10.1016/j.envsci.2009.01.010

Negash, M., Starr, M., Kanninen, M., \& Berhe, L. (2013). Allometric equations for estimating aboveground biomass of Coffea arabica L. grown in the Rift Valley escarpment of Ethiopia. Agroforest System, 87, 953-966. https://doi.org/10.1007/s10457-013-9611-3

Ni, J. Z., Pignatello, J. J., \& Xing, B. S. (2010). Adsorption of aromatic carboxylate ions to black carbon (biochar) is accompanied by proton exchange with water. Environmental Science and Technology, 45, 9240-9248. https://doi.org/10.1021/es201859j

Noponen, M. R. A., Healey, J. R, Soto, G., \& Haggar, J. P. (2013). Sink or source-The potential of coffee agroforestry systems to sequester atmospheric $\mathrm{CO} 2$ into soil organic carbon. Agriculture, ecosystems and Environment, 175, 60-68. https://doi.org/10.1016/j.agee.2013.04.012

Pearson, T. R., Brown. S. L., \& Birdsey, R. A. (2007). Measurement guidelines for the sequestration of forest carbon, general technical report, USAD forest service.

Pietikäinen, J., \& Fritze, H. (1993). Microbial biomass and activity in the humus layer following burning: short-term effects of two different fires. Canadian Journal of Forest Research, 23, 1275-1285. https://doi.org/10.1139/x93-163

Regmi, B. D., Poudel, C., Tripathi, B. P., Schulz, S., \& Dhital, B. K. (2005). Managing soil fertility problems of 
marginal agricultural lands through integrated plant nutrient systems: Experiences from the hills of Nepal. Micronutrients in South and Southeast Asia, Procs. Int'l. Workshop held 8-11 Sep. 2004. Andersen P, Tuladhar JK, Karki KB and Maskey SL (eds.) Kathmandu, Nepal. P 109-119.

Roshetko, J. M., Delaney, M., Hairiah, K., \& Purnomosidhi, P. (2002). Carbon stocks in Indonesian homegarden systems: can smallholder systems be targeted for increased carbon storage?. Am J Alt Agriculture, 17, 138-148. https://doi.org/10.1079/AJAA200116

Sanderman, J., \& Jeffrey, A. B. (2010). Accounting for soil carbon sequestration in national inventories: a soil scientist's perspective. Environ. Res. Lett. 5, 034003. https://doi.org/10.1088/1748-9326/5/3/034003

Schmitt-Harsh, M., Evans, T. P., Castellanos, E., \& Randolph, J. C. (2012). Carbon stocks in coffee agroforests and mixed dry tropical forests in the western highlands of Guatemala. Agroforest Syst, 86, 141-157. https://doi.org/10.1007/s10457-012-9549-x

Segura, M., Kanninen, M., \& Suarez, D. (2006). Allometric models for estimating aboveground biomass of shade trees and coffee bushes grown together. Agroforest system, 68, 143-150. https://doi.org/10.1007/s10457-006-9005-x

Schreier, H., \& Shah, P. B. (1999). Soil fertility status and dynamics in the Jhikhu and Yarsha Khola watershed. In R. Allen, H. Schreier, S. Brown, \& P. B. Shah (Eds.), The people and resource dynamics project: The first three years (1996-1999) (pp. 281-299).

Sharma, R. K., Sankhayan, P. L., \& Hofstad, O. (2008). Forest biomass density, utilisation and production dynamics in a western Himalayan watershed. Journal of Forestry Research, 19, 171-180. https://doi.org/10.1007/s11676-008-0032-5

Sherchan, D. P., \& Karki, K. B. (2005). Plant nutrient management for improving crop productivity in Nepal. In: Proceedings of regional workshop on improving plant nutrient management for better farmer livelihood, food security and environmental sustainability, pp 41-57. December 12-16. Beijing, China.

Sitaula, B. K., Bajracharya, R. M., \& Singh, B. R. (2004). Factors Affecting Organic Carbon Dynamics in Soils of Nepal/ Himalaya Region - A Review and Analysis. Nutrient Cycling in Agro-ecosystems, 70(2), 215-229. https://doi.org/10.1023/B:FRES.0000048474.85331.7d

Soto-Pinto, L., Anzueto, M., Mendoza, J., Ferrer, G. J., \& de Jong, B. (2010). Carbon sequestration through agroforestry in indigenous communities of Chiapas, Mexico. Agroforest System, 78, 39-51. https://doi.org/10.1007/s10457-009-9247-5

SSMP (2009). Farmer Profiles from the Mid-hills of Nepal. Helvetas - Sustainable Soil Management Programme. Document No. 51. Kathmandu, Nepal.

Suwal, M. R. S., Subedi, K. D., \& Gurung, G. (1991). Soil fertility thrust towards sustainable agriculture: experience of Lumle Regional Agricultural Research Centre. In P.B. Shah, H. Schreier, S.J. Brown, \& K.W. Riley (Eds.), Soil fertility and erosion issues in the Middle Mountains of Nepal (pp. 61-82).

Tamang, D. (1991). Indigenous soil fertility management systems in the hills of Nepal. In P.B. Shah, H. Schreier, S.J. Brown, \& K.W. Riley (Eds.), Soil fertility and erosion issues in the Middle Mountains of Nepal (pp. 135-151).

Verchot, L., Van Noordwijk, M., Kandji, S., Tomich, T. P., Ong, C., Albrecht, A., Mackensen, J., Bantilan, C., Anupama, K. V., \& Palm, C. A. (2007). Climate change: linking adaptation and mitigation through agroforestry. Mitigation and Adaptation Strategy for Global Change, 12, 901-918. https://doi.org/10.1007/s11027-007-9105-6

\section{Copyrights}

Copyright for this article is retained by the author(s), with first publication rights granted to the journal.

This is an open-access article distributed under the terms and conditions of the Creative Commons Attribution license (http://creativecommons.org/licenses/by/3.0/). 